\title{
INTERACTION OF 4 ALLOTROPIC MODIFICATIONS OF CARBON NANOPARTICLES WITH LIVING TISSUES
}

\author{
S. Ya. PARYZHAK ${ }^{1}$, T. I. DUMYCH ${ }^{1}$, S. M. PESHKOVA ${ }^{1,2}$, \\ E. E. BILA ${ }^{2}$, A. D. LUTSYK ${ }^{1}$, A. BARRAS ${ }^{3}$,

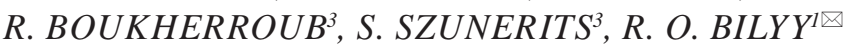 \\ ${ }^{1}$ Danylo Halytsky Lviv National Medical University, Ukraine; \\ ${ }^{2}$ Ivan Franko Lviv National University, Ukraine; \\ ${ }^{3}$ Univ. Lille, CNRS, Centrale Lille, ISEN, Univ. Valenciennes, France; \\ 凶e-mail: r.bilyy@gmail.com
}

Received: 19 January 2019; Accepted: 20 March 2019

Environmental pollution and technological progress lead to carbon nanoparticles that pose a serious health risk. They are present in soot, dust, and printing toner and can also be formed during grinding and cutting. Human neutrophils are able to sequester foreign material by formation of neutrophil extracellular traps (NETS), a process that can cause a strong inflammatory response. In the current work we compared proinflammatory properties of different carbon-based nanostructures: nanodiamonds, graphene oxide, fullerenes $C_{60}$ and carbon dots. We tested adjuvant properties of carbon nanoparticles in a murine immunization model by investigating humoral (specific Ig G and IgM antibodies) and cellular (delayed type hypersensitivity) immune responses. The ability of NETs to sequester nanoparticles was analyzed in a mouse air pouch model and neutrophil activation was verified by in vivo tracking of near-infrared labeled nanodiamonds and ex vivo fluorescent assays using human blood-derived neutrophils. All carbon nanoparticles exhibited proinflammatory adjuvant-like properties by stimulating production of specific IgG but not IgM antibodies (humoral immune response). The adjuvant-like response decreased in this order: from nanodiamonds, graphene oxide, fullerenes $C_{60}$ to carbon dots. None of the studied carbon nanoparticles triggered a delayed type hypersensitivity reaction (cellular immune response). Nanodiamonds and fullerenes $C_{60}$ were sequestrated in the body by NETS, as confirmed in the air pouch model and by in vivo fluorescent tracking of near-infrared labeled nanodiamonds.

Ke y w ords: carbon-based nanostructures, immune response, inflammation, neutrophil extracellular traps (NETS).

$\mathrm{N}$ anoparticles (NPs) are formed during circumstances such as coal mining, laser printing, and forest or other fires. In the human body, a large amount of natural NPs (nanocrystals) are formed. Nanocrystals of monosodium urate are able to activate neutrophils to modulate the inflammatory processes during gout [1] and to induce cell necroptosis in kidney disease $[2,3]$. Recently it was described that nanodiamonds (ND) $(\sim 10 \mathrm{~nm})$ are entrapped by neutrophils which leads to initiation of the size-dependent inflammatory response [4]. Neutrophils are the first line of the body's defense system against particulate agents. Neutro- phils form neutrophil extracellular traps (NETs) in response to exogenous (e.g., pathogens, nanosized particles) and endogenous particulate triggers (e.g., urate crystals, oxalates) or chemicals (e.g., bicarbonate, toxins). NETs are extracellular networks of decondensed chromatin, cytosolic and granule proteins [5], that depend on reactive oxygen species [6] and specific enzymes to form. NETs try to localize inflammation [7] and limit the spread of tissue damaging agents [8].

The human body does not have any molecular pathway to oxidize carbon nanoparticles, as soot/ diamonds/graphene are oxidized at high tempera-

(c) 2019 Paryzhak S. Ya. et al. This is an open-access article distributed under the terms of the Creative Commons Attribution License, which permits unrestricted use, distribution, and reproduction in any medium, provided the original author and source are credited. 
tures; besides a specific receptor to bind these hydrophobic particles for targeted phagocytosis is also not known. Dust or coal particle accumulation in the lungs of smokers or coal miners, respectively, is a well-known phenomenon.

In this study we aimed to compare the proinflammatory properties of 4 allotropic carbon modifications in nanocomposite form: ND, graphene oxide (GO), fullerenes $\mathrm{C}_{60}\left(\mathrm{C}_{60}\right)$ and carbon dots (C-dots) with the aim to estimate their safety and potential as adjuvant compounds upon controlled application.

\section{Materials and Methods}

Materials. Aluminum hydroxide $\left(\mathrm{Al}(\mathrm{OH})_{3}\right)$, chicken egg ovalbumin (OVA), 3,3',5,5'-tetramethybezidine (TMB), phorbol 12-myristate 13-acetate (PMA) and $\mathrm{C}_{60}$ were purchased from Sigma-Aldrich, USA.

$\mathrm{ND}, \mathrm{GO}$ and C-dots were produced by the NanoBiointerface group (Institute of Electronics, Microelectronics and Nanotechnology, University of Lille, France).

Animals. 6- to 8-week-old male Balb/c mice (Danylo Halytsky Lviv National Medical University, Ukraine) were used for immunization experiments. Swiss nude mice (Charles River, France) were used for in vivo biodistribution studies. Mice were housed in cages in a temperature-controlled room with a $12 \mathrm{~h}$ light and $12 \mathrm{~h}$ dark schedule and kept on a standard diet with water available ad libitum. Studies involving animals, including housing and care, method of euthanasia, and experimental protocols were approved by the Ethical committee of Danylo Halytsky Lviv National Medical University and University of Lille, protocol 20170918/8 \& 201703021400830. In total, 53 mice were analyzed: 30 mice were immunized ( $n=5$ per group); 20 mice were used for the air pouch study ( $n=4$ per group) and 3 mice were used for the biodistribution assay.

Murine immunization model. $50 \mu \mathrm{g}$ of OVA was injected intraperitoneally in the presence of adjuvant $\left(\mathrm{Al}(\mathrm{OH})_{3} 1 \mathrm{mg}\right.$; GO $50 \mu \mathrm{g}$; C-dots $50 \mu \mathrm{g}$; $\mathrm{C}_{60} 50 \mu \mathrm{g}$; ND $50 \mu \mathrm{g}$ ) or alone as negative control at day 1 and day 15 of the experiment. Blood was collected from the tail at day 0,14 and 35. The presence of anti-OVA antibodies was measured before immunization (day 0), and at 14 and 35 days after immunization. The delayed-type hypersensitivity (DTH) test was performed 28 days after the $1^{\text {st }}$ immunization by injection of $5 \mu \mathrm{g}$ of OVA in $50 \mu$ of phosphate buffered saline (PBS) into the right hind paw. Injec- tion of $50 \mu 1$ of PBS into the left hind paw was used as a control. The thickness of the paw was measured with a caliper (B110T, Kroeplin Laengenmesstechnik; Schlüchtern, Germany) before the injection and $24 \mathrm{~h}$ after it, as described [4].

Air pouch model. The air pouch model [9] was performed by injection of $5 \mathrm{ml}$ of sterile air subcutaneously into the back of Balb/c mice to form an air pouch. In two days, an additional $2 \mathrm{ml}$ of sterile air were blown into the pouch. Two days later, $1 \mathrm{mg}$ of GO, C-dots, $\mathrm{C}_{60}$ or ND in PBS or PBS only were injected into the air pouches. On the next day, mice were sacrificed and the air pouch membranes were analyzed.

Enzyme-linked immunosorbent assay (ELI$S A)$. For determination of serum anti-OVA IgG and IgM, immunosorbent NUNC MaxiSorp plates were coated with $50 \mu \mathrm{l}$ per well of $5 \mu \mathrm{g} / \mathrm{ml}$ solution of OVA in $100 \mathrm{mM}$ carbonate-bicarbonate buffer (pH 9.6). Plates were incubated overnight at $4{ }^{\circ} \mathrm{C}$ and washed three times with PBS supplemented with 0.05\% Tween (PBS-T). The plates were blocked with $4 \%$ bovine serum albumin (BSA) in PBS-T for $2 \mathrm{~h}$ at $37{ }^{\circ} \mathrm{C}$. All serum samples were diluted 1:2 000 in washing buffer and incubated at $37^{\circ} \mathrm{C}$ for $1 \mathrm{~h}$, after that the plates were washed again. Goat AntiMouse IgG(H+L)-HRP (115-035-003 Jackson ImmunoResearch, Ely, UK) or goat anti-mouse IgMHRP (Jackson ImmunoResearch, 115-035-020) were diluted in washing buffer (1:10 000), added to the plates and incubated at room temperature for $1 \mathrm{~h}$. After the proper washings, the assay was developed with TMB containing $\mathrm{H}_{2} \mathrm{O}_{2}$ as a substrate. The reaction was stopped with $50 \mu \mathrm{l}$ per well of $0.5 \mathrm{M}$ sulfuric acid. The absorbance was read at 450 and $620 \mathrm{~nm}$ reference wavelengths using the BioAssay Reader HST 7000 (Perkin Elmer, Waltham, MA, USA).

Analysis of DNA externalization. Human granulocytes were isolated from heparinized venous blood of normal healthy donors by Lymphoflot (Bio-Rad, Hercules, CA, USA) density gradient centrifugation. The granulocyte-rich layer on the top of red blood cells (RBCs) was taken and subjected to hypotonic lysis of RBCs. Isolated granulocytes were routinely checked for viability [10] and placed in 96-well culture plates at $5 \times 10^{6}$ cells per milliliter with indicated inducers of NETosis in the presence of fluorescent nucleic acid dye SYTOX Green (Life Technologies, Waltham, MA, USA). Since granulocytes are not permeable to the dye, only externalized DNA was measured by the assay; untreated neutro- 
phils served as a background, since after isolation they were prone to spontaneous NETs formation [1], PMA was used as a strong inducer (positive control). The fluorescence was measured in kinetics for 4 h using the BioAssay Reader HTS7000 (Perkin Elmer), excitation 480/15 nm, emission 535/20 nm.

Nanoparticle labeling and in vivo tracking of nanoparticle distribution. Labeling of ND with near-infrared fluorescent dye CF790 (Sigma-Aldrich, St. Louis, MO, USA) was performed according to the recommendations of the manufacturer. Briefly, CF790 was diluted in dimethyl sulfoxide to a final concentration of $10 \mathrm{mM}$. $30 \mathrm{uL}$ of this solution was mixed with $5 \mathrm{mg}$ of the NPs $(2.5 \mathrm{mg} / \mathrm{ml}$, previously dissolved in $0.1 \mathrm{M}$ sodium bicarbonate buffer, $\mathrm{pH}$ 8.3). The reaction solution was incubated at room temperature for $1 \mathrm{~h} .50 \mathrm{uL}$ of $1 \mathrm{M}$ lysine was added to stop the reaction.

$1 \mathrm{mg}$ of labeled NPs was injected intraperitoneally into Swiss nude mice. In vivo tracking of labeled ND was performed with a Bruker In-Vivo Xtreme system (Billerica, MA, USA) supplied with an interline front-illuminated (FI) 16 MP CCD detector, a 400 W Xenon Fluorescence illuminator (excitation $760 \mathrm{~nm}$, emission $830 \mathrm{~nm}$ ) and integrated heating module. The data were analyzed by highperformance Bruker Molecular Imaging (MI) software. Photos represent mirror images of the mice. Animals were anesthetized with isoflurane-oxygen mixture during the imaging procedure. The imaging (exposure time) lasted 40s.

Statistical analyses. All calculations were performed using Excel 2016 (Microsoft, Redmond, WA, USA) and Prism 7.0 (GraphPad, San Diego, CA, USA) software. The results were represented as the median \pm IQR (animal assay) and mean \pm SEM (DNA externalization), with $n$ of minimum 3 to 5 values for animal experiments according to 3R Principles (exact value is indicated in figure legend). For the calculation of statistical differences in the animal assay the Kruskal-Wallis test was used, for DNA externalization the $t$-test was used. $\mathrm{P}$ value of 0.05 was considered statistically significant. Three levels of significance were used: * $P<0.05$; $* * P<0.01$; *** $P<0.001$.

\section{Results and Discussion}

In our work we compared proinflammatory properties of carbon-based nanomaterials such as ND, GO, $\mathrm{C}_{60}$ and C-dots. To study adjuvant properties of carbon nanocomposites we utilized the murine immunization model, which has been available for more than 50 years [11-13]. For testing the immunogenic properties of the particles, injection without adjuvant with model antigen OVA was used as a negative control [12], in this case stimulation of antibody production indicated the proinflammatory properties of the studied nanocomposites.

The humoral immune response was estimated by detection of specific anti-OVA IgG and IgM antibodies at day 0 (before immunization), and then at 14 and 35 days post immunization. All of the used carbon-based NPs did not induce production of IgM antibodies associated with the acute phase response; at sera dilution 1:2 000 the absorbance (optical density, OD) was below 0.05 (not shown). Specific antiOVA IgG were not detected on day 0 (negative control). At 14 days after immunization with OVA in the presence of GO, ND and aluminum hydroxide (Alum), anti-OVA IgG started to form, although the difference was insignificant. A significantly higher amount of anti-OVA IgG antibodies was observed 35 days after the first immunization (Fig. 1). The humoral immune response for C-dots was not statistically significant compared to OVA alone. Other studied carbon NPs (GO, ND and $\mathrm{C}_{60}$ ) and Alum (used as positive control) stimulated the formation of specific anti-OVA IgG (day 35) as compared to OVA injection without adjuvant (Fig. 1).

The cellular immune response against OVA was evaluated on day 28 using a model of the DTH reaction, which represents the T2-mediated cellular response [14]. OVA was injected in the paws of mice immunized with antigen in the presence of carbon-based nanomaterials. The footpad swelling was measured $24 \mathrm{~h}$ after the injection and compared with the value before injection; the measurements were done with a custom adapted micrometer. A T2-cell associated cellular immune response was not detected for C-dots. Other compounds also did not show statistically different results as compared to OVA alone (Fig. 2). We concluded that the studied NPs did not mediate a DTH reaction (T2-cellular immune response), which we considered as a good sign of the ability to prevent adverse hyper-reactivity effects [15].

To investigate the fate of carbon-based nanomaterials after their injection into the body, an air pouch model was utilized (Fig. 3, A). Formed air pouch cavities were filled with exudate and mononuclear cells within 24h. Neutrophils in the air pouch responded to inflammatory stimuli and tended to en- 


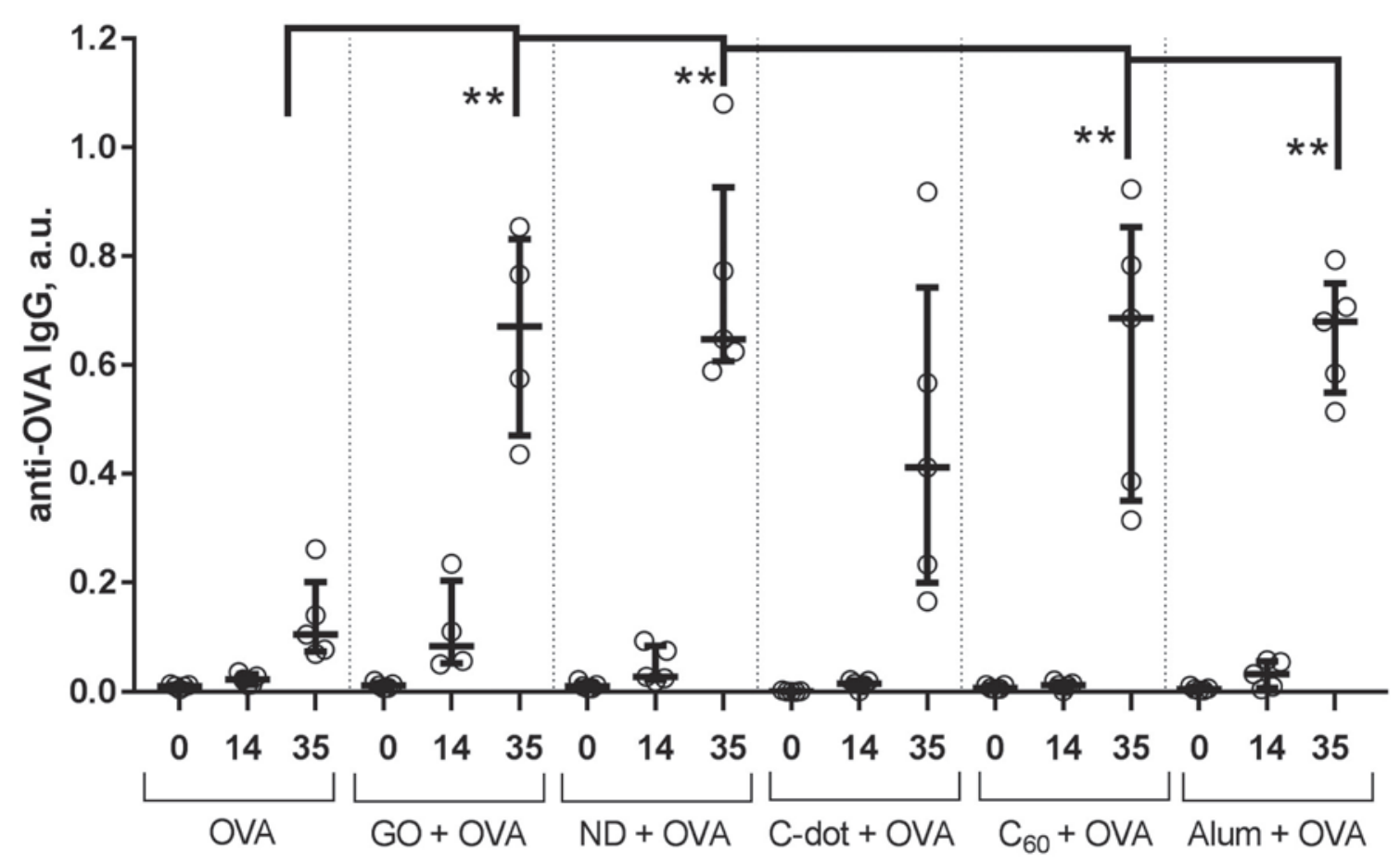

Fig. 1. Humoral immune response (anti-OVA $\operatorname{IgG}$ ) detected in mice sera after immunization with ovalbumin (OVA) in the presence of indicated carbon nanoparticles; Aluminum hydroxide (Alum) served as positive control. Injection of OVA without adjuvant was used as a negative control. Sera were collected before (day 0), and at 14 and 35 days after immunization. Levels of significance are represented for day 35: ** P<0.01 observed for OVA vs ND+OVA; OVA vs GO+OVA; OVA vs $C_{60}+O V A ;$ OVA vs Alum+OVA. $C_{60}$, fullerenes $C_{60}$; $C$-dots, carbon dots; $G O$, graphene oxide; $N D$, nanodiamonds

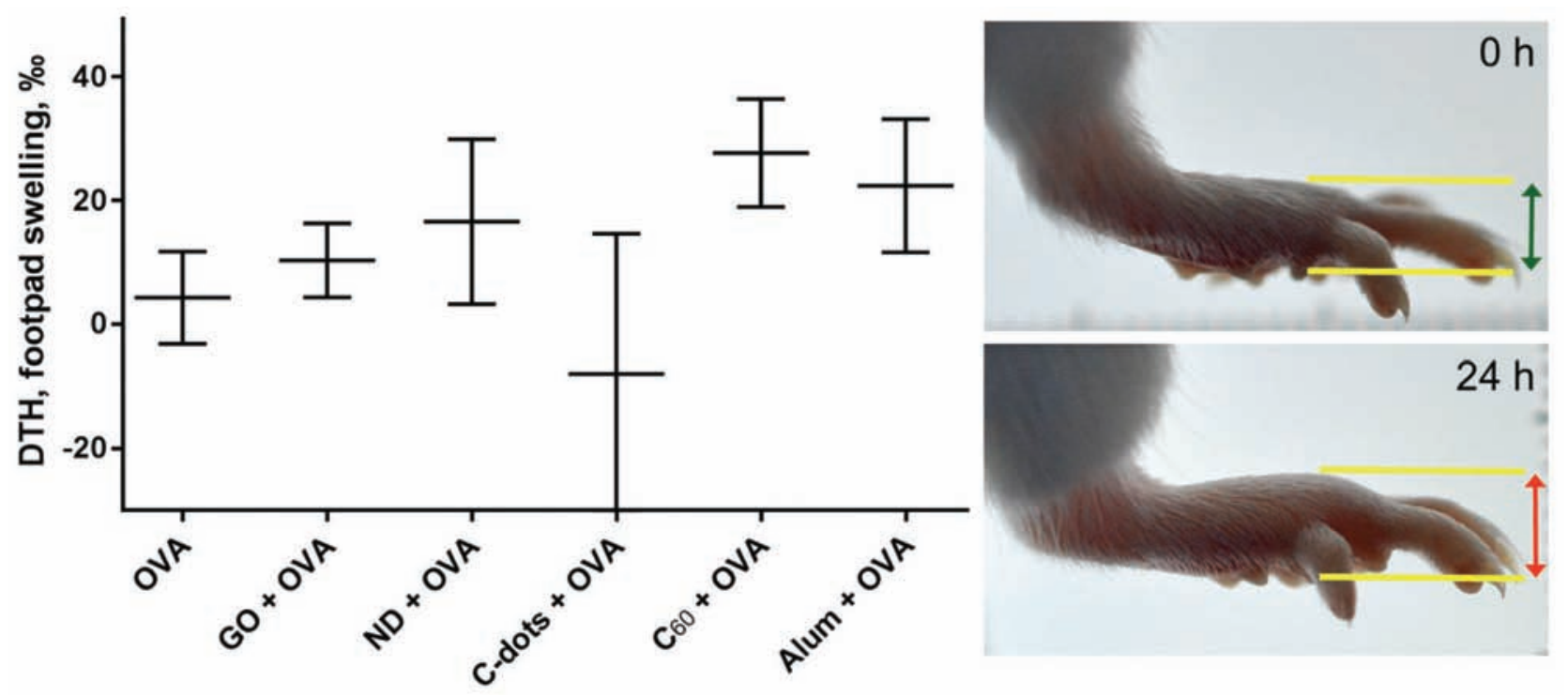

Fig. 2. Cellular immune response. The delayed-type hypersensitivity (DTH) reaction at $24 \mathrm{~h}$ after injection of OVA in mice immunized with the antigen in the presence of ND, GO, Alum (aluminum hydroxide), C-dots or $C_{60}$. Mice immunized with OVA without adjuvant were used as a negative control. $C_{60}$, fullerenes $C_{60}$; $C$-dots, carbon dots; GO, graphene oxide; ND, nanodiamonds; OVA, ovalbumin 

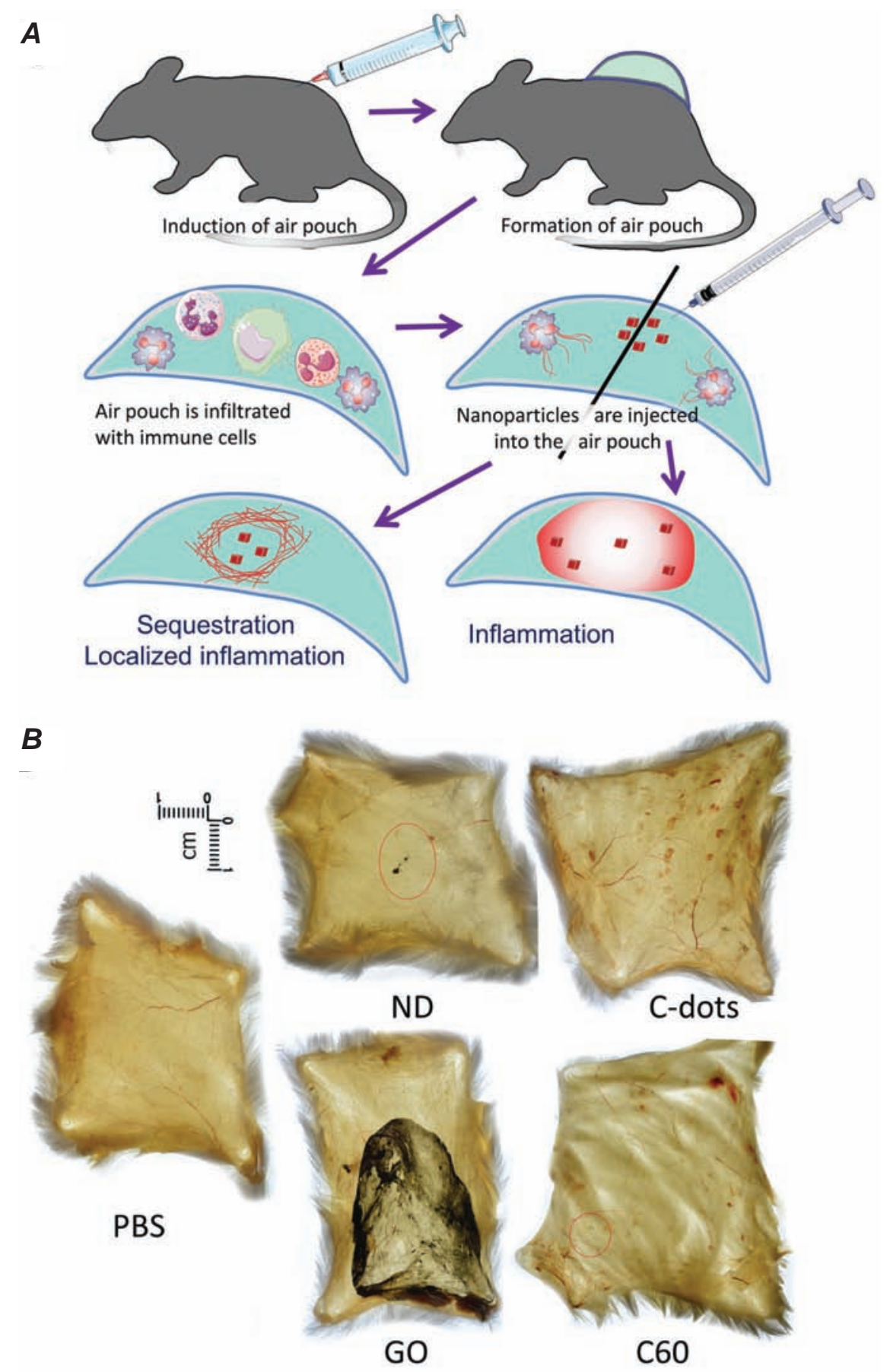

Fig. 3. Formation of neutrophil extracellular traps (NETs) in the air pouches. A - scheme of the experiment. Sterile air was injected under the skin for formation of cavity. In four days nanoparticles were injected into the air pouch, the pouch already being infiltrated with immune cells. $\boldsymbol{B}$-analysis of the skin after inoculation with phosphate buffered saline (PBS) (negative control), $1 \mathrm{mg}$ of ND, C-dots, GO or $C_{60}$ in PBS. Neutrophils tended to sequestrate nanoparticles and localized the inflammation (indicated with red circles). Figures are representative images of $n=4$ animals analyzed. $C_{60}$, fullerenes $C_{60} ; C$-dots, carbon dots; $G O$, graphene oxide; $N D$, nanodiamonds 
gulf NPs via NETs, as earlier demonstrated for ND [4]. Carbon NPs were injected into the air pouch. After $24 \mathrm{~h}$ mice were sacrificed and the skin was analyzed.

After the injection into air pouches ND and $\mathrm{C}_{60}$ were entrapped in NETs (Fig. 3, B). C-dots and $\mathrm{C}_{60}$ led to edema and damage of capillaries with the formation of small erythema. GO was not engulfed by macrophages, thus it covered the walls of the airfilled cavity and formed a thin black film with some erythema. ND were sequestrated and showed neither damage of blood vessels nor swelling.

To understand the influence of carbon-based nanocomposites (ND, $\mathrm{C}_{60}$, C-dots and GO) on neutrophil activation these nanomaterials were used to stimulate NETs formation in human blood-derived neutrophils. Neutrophils were isolated from the venous blood of healthy donors. PMA was used as a strong inducer of NETs formation (positive control). Extracellular DNA released by the treatment with the stimuli was detected by staining with the fluorescent dye SYTOX Green. $\mathrm{C}_{60}$ could not be used because of insolubility and precipitation. GO absorbed the fluorescent signal and was not detectable by means of fluorescence. Stimulation with C-dots was not significantly different from the spontaneous activation of neutrophils (negative control). In contrast, NETs formation was observed upon contact of isolated neutrophils with ND. The results were statistically significant as compared to spontaneous activation of neutrophils (Fig. 4).

To follow up the distribution of ND in the body, mice were injected intraperitoneally with $1 \mathrm{mg}$ of ND labeled with fluorescent dye CF790 (NDCF790). For monitoring of fluorescent compound in the body we used the In-Vivo Xtreme fluorescent scanner (Bruker). We detected a strong fluorescent signal (excitation $760 \mathrm{~nm}$, emission $830 \mathrm{~nm}$ ) in 5 hours at the place of injection. The intensity of the signal gradually decreased and disappeared after 168 hours (Fig. 5). ND were entrapped in NETs (as shown for the air pouch model), and were localized at the place of injection in granuloma-like structures. We failed to observe any transfer of fluorescent signal to blood, urine or gall, instead the dye was gradually oxidized at the place of injection and lost its fluorescence.

Our data demonstrate that carbon NPs did not stimulate production of acute phase IgM antibodies towards co-injected antigen, they also did not induce DTH in the studied animals. Still, most of the studied carbon nanocomposites stimulated production of $\mathrm{IgG}$ antibodies in a humoral immune response towards co-injected model antigen. Thus the studied NPs possessed some proinflammatory activities. Besides, some of them like ND, were effectively

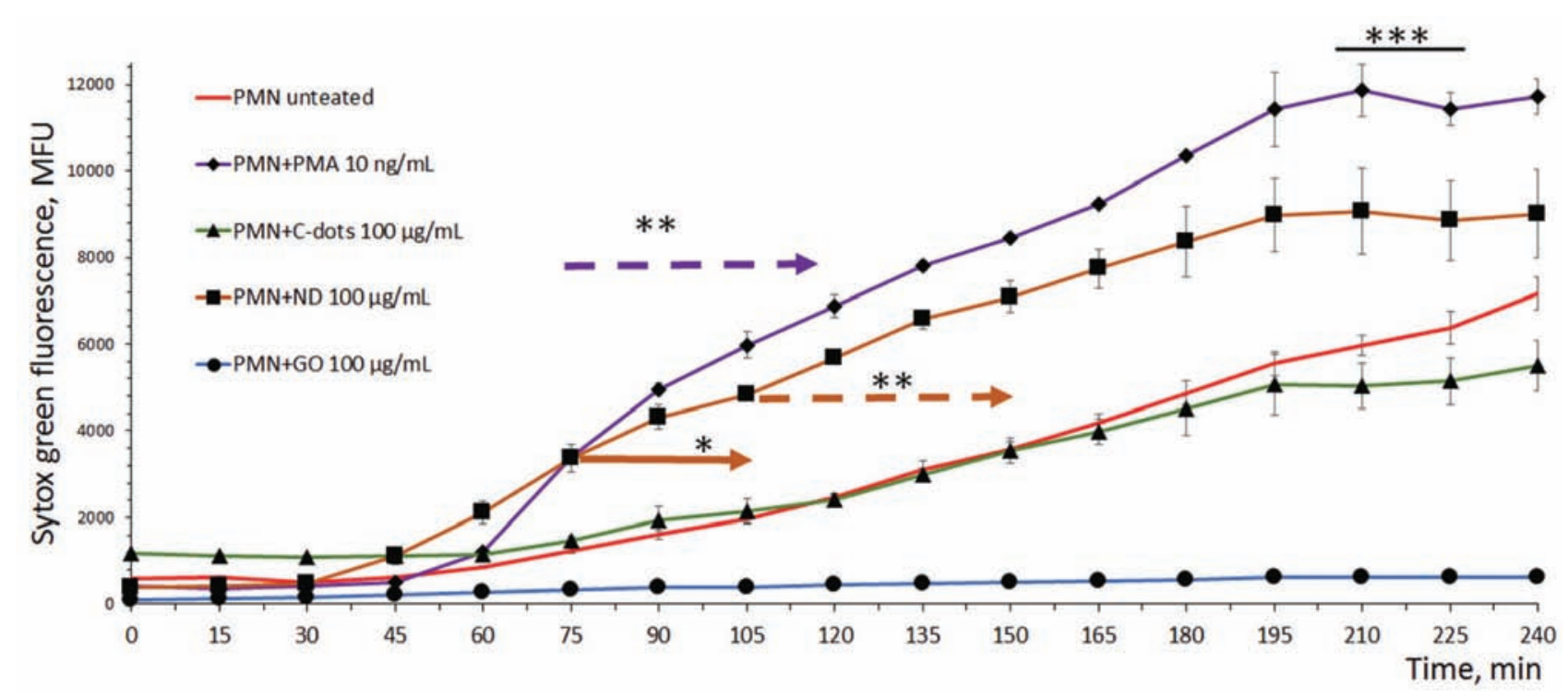

Fig. 4. DNA externalization in the isolated polymorphonuclear cells (PMN) after co-incubation with carbon nanoparticles measured with the fluorescent dye SYTOX Green. Starting at 75 min the data points of $P M N+P M A(10 \mathrm{ng} / \mathrm{ml})$ and $P M N+N D(100 \mu \mathrm{g} / \mathrm{ml})$ were significantly different from values for PMN untreated. ${ }^{*} P<0.05 ;{ }^{* *} P<0.01$. C-dots, carbon dots; GO, graphene oxide; ND, nanodiamonds, PMA, phorbol 12-myristate 13-acetate 


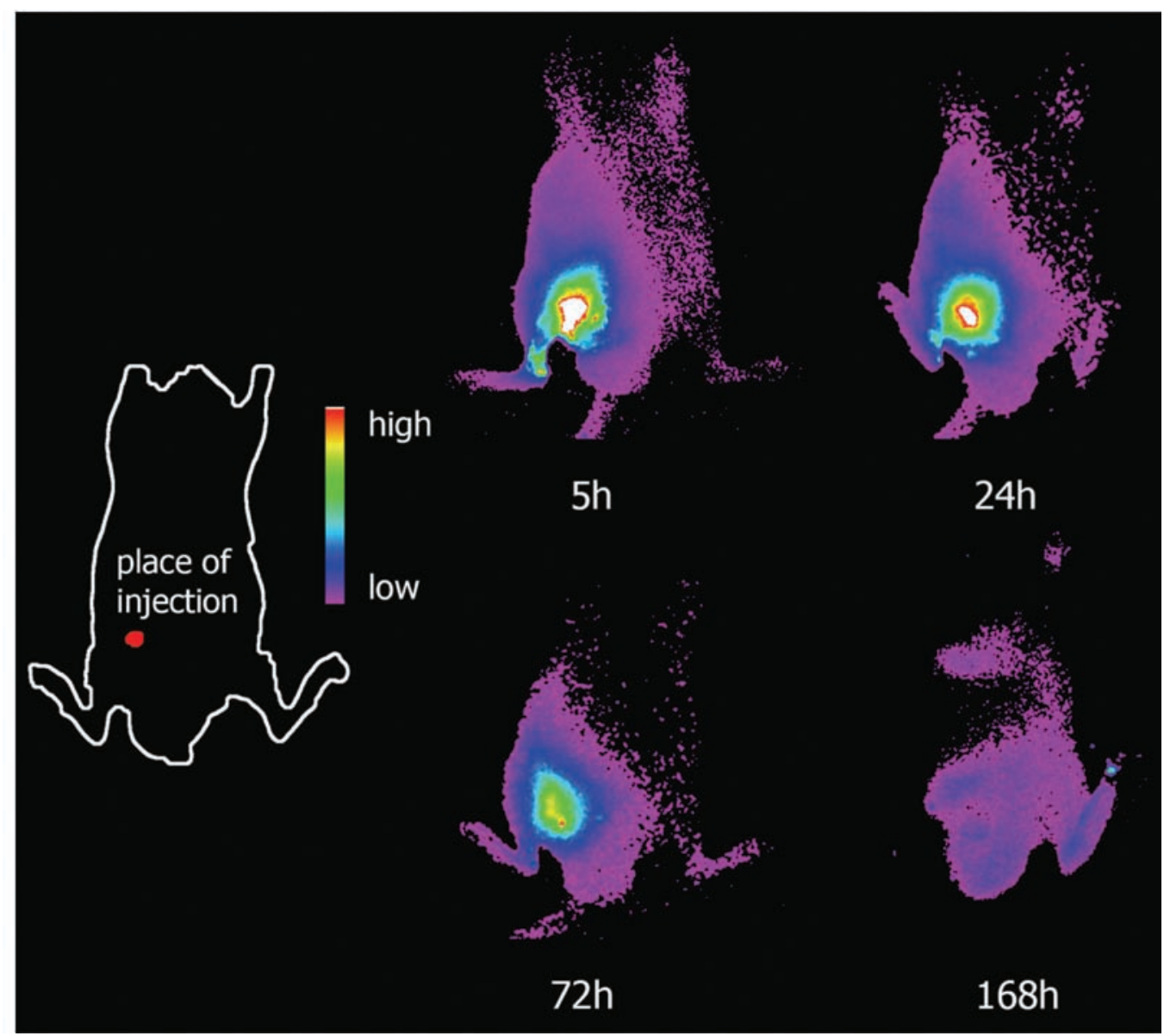

Fig. 5. Distribution of ND-CF790 solution in the body of mice at 5, 24, 72 and 168 h after intraperitoneal injection. Fluorescence images were obtained by Bruker In-Vivo Xtreme imager using excitation $760 \mathrm{~nm}$ and emission $830 \mathrm{~nm}$. Representative image of 3 mice analyzed.

entrapped with NETs, providing the possibility of having a localized immune response at the place of injection. The observed NET-inducing properties of carbon NPs can be used to create efficient adjuvants and novel delivery systems that enhance immunogenicity and are increasingly needed as we move toward the newest vaccines. These data are also important for a better understanding of tissue damage by carbon-based pollutants like soot.

In fact, NETs involvement in mediation of alum action as an adjuvant was reported recently [16], while modification of shape of alum components resulted in the significant enhancement of adjuvant properties [15]. ND as well as hydrophobic polystyrene NPs demonstrated a strong adjuvant effect acting via a self-limiting immune activation involving NETs formation [4], this was true even in the condition of sterile inflammation [17]. GO was reported as a cytotoxic agent, depending on the dose, size and thickness of the GO layer; GO can attenuate the immune response [18] and reduced GO has been used as a heat absorbing agent in different medical applications [19]. As we demonstrated, the studied GO was not localized by NETs but occupied the entire space of the air pouch cavities, thus its safety upon application inside the body should be carefully considered, as neutrophils are unable to sequester this type of nanocomposite. Carbon nanotubes are able to damage the plasma membrane and cause lipid redistributions as well [20]. At relatively high concentrations C-dots can exhibit cytotoxicity and modulate humoral immune response [21]. Conflicting data concerning the adjuvant properties of the water-soluble $\mathrm{C}_{60}$ derivatives are found in the literature. Some studies reported that immunization with $\mathrm{C}_{60}$ derivatives leads to the formation of specific IgG antibodies [22], while other work showed that $\mathrm{C}_{60}$ derivatives did not induce any antibody response [23]. In the current study, we used fullerenes $\mathrm{C}_{60}$, very hydrophobic and made of only carbon atoms. 
In this work, we were able to compare the proinflammatory properties of 4 carbon nanocomposites (ND, GO, $\mathrm{C}_{60}$, C-dots) and estimate their fate in the body upon injection.

Conclusions. All allotropic modifications of carbon exhibited proinflammatory properties, acting as adjuvants in initiation of the humoral immune response, as judged by production of specific $\operatorname{IgG}$ antibodies. The adjuvant-like response decreased in this order: from ND, GO, $\mathrm{C}_{60}$ to C-dots. None of the studied carbon NPs triggered a T2-mediated cellular immune response. ND and $\mathrm{C}_{60}$, but neither GO nor C-dots, could be passivated in the body through entrapment by NETs. Upon intraperitoneal injection, the nanoparticles did not spread throughout the body, thus their proinflammatory action was localized.

Conflict of interest. Authors have completed the Unified Conflicts of Interest form at http:// ukrbiochemjournal.org/wp-content/uploads/2018/12/ coi_disclosure.pdf and declare no conflict of interest.

Acknowledgements. This project has received funding from the European Union's Horizon 2020 Research and Innovation Staff Exchange (RISE) Marie Skłodowska-Curie Actions under grant agreement No 690836 and Grants from the Ministry of Healthcare of Ukraine. We are thankful to CedarsSinai Medical Center's International Research and Innovation in Medicine Program, and the Association for Regional Cooperation in the Fields of Health, Science and Technology (RECOOP HST Association) for their support. We thank Dr V'yacheslav Lehen'kyi (Université de Lille) for his help with in vivo imaging.

\section{ВЗАЕМОДІЯ ЧОТИРЬОХ \\ АЛОТРОПНИХ МОДИФІКАЦІЙ КАРБОНОВИХ НАНОЧАСТИНОК ІЗ ТКАНИНАМИ ОРГАНІЗМУ}

\author{
С. Я. Парижак 1 , Т. I. Думич ${ }^{1}$, \\ С. М. Пешкова ${ }^{1,2}$, С. С. Біла'ㄹ, О. Д. Луциик ${ }^{1}$, \\ А. Баррас 3 , Р. Букеррубб, С. Сзунерітс ${ }^{3}$, \\ Р. О. Білий
}

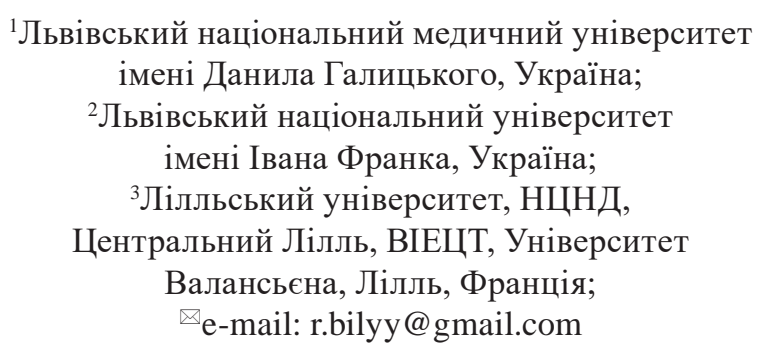

Забруднення навколишнього середовища та технологічний прогрес призводять до утворення вуглецевих наночастинок, які становлять серйозний ризик для здоров'я. Вони присутні в сажі, пилу, тонері для друку і можуть виникати за шліфування та фрезерування матеріалів. Нейтрофіли людини здатні ізолювати чужорідний матеріал шляхом утворення нейтрофільних позаклітинних пасток (НПП), останні здатні стимулювати сильну запальну відповідь. У роботі було порівняно прозапальні властивості різних наноструктур на основі вуглецю: нанодіамантів, графен оксиду, фулеренів $\mathrm{C}_{60} \mathrm{i}$ вуглецевих точок. Було протестовано ад'ювантні властивості вуглецевих наночастинок у моделі імунізації мишей за дослідження гуморальної (специфічні IgG і IgM антитіла) та клітинної (гіперчутливість сповільненого типу) 
імунної відповіді. Здатність НПП секвеструвати наночастинки вивчено на моделі повітряної кишені мишей, a активацію нейтрофілів перевірено шляхом відстеження флуоресцентно мічених нанодіамантів in vivo, та флуоресцентним аналізом із застосуванням нейтрофілів людини ex vivo. Усі вуглецеві наночастинки виявляли прозапальні ад’ювантні властивості, стимулюючи продукцію специфічних $\mathrm{IgG}$, але не IgM антитіл (гуморальна імунна відповідь). Ад'ювантні властивості зменшувались упорядку від нанодіамантів, графен оксиду, фулеренів $\mathrm{C}_{60}$ до вуглецевих точок. Жодна із досліджуваних вуглецевих наноструктур не спричинювала появу реакції гіперчутливості сповільненого типу (клітинна імунна відповідь). Нанодіаманти і фулерени $\mathrm{C}_{60}$ були секвестровані в організмі НПП, що підтверджено на моделі повітряної кишені, і шляхом відстеження флуоресцентно мічених нанодіамантів in vivo.

Кл юч ов і слова : наноструктури на основі вуглецю, імунна відповідь, запалення, нейтрофільні позаклітинні пастки (НПП).

\section{References}

1. Pieterse E, Jeremic I, Czegley C, Weidner D, Biermann MH, Veissi S, Maueröder C, Schauer C, Bilyy R, Dumych T, Hoffmann M, Munoz LE, Bengtsson AA, Schett G, van der Vlag J, Herrmann M. Blood-borne phagocytes internalize urate microaggregates and prevent intravascular NETosis by urate crystals. Sci Rep. 2016; 6(1): 38229.

2. Mulay SR, Desai J, Kumar SV, Eberhard JN, Thomasova D, Romoli S1, Grigorescu M, Kulkarni OP, Popper B, Vielhauer V, Zuchtriegel G, Reichel C, Bräsen JH, Romagnani P, Bilyy R, Munoz LE, Herrmann M, Liapis H, Krautwald S, Linkermann A, Anders HJ. Cytotoxicity of crystals involves RIPK3-MLKL-mediated necroptosis. Nat Commun. 2016; 7: 10274.

3. Schauer C, Janko C, Munoz LE, Zhao Y, Kienhöfer D, Frey B, Lell M, Manger B, Rech J, Naschberger E, Holmdahl R, Krenn V, Harrer T, Jeremic I, Bilyy R, Schett G, Hoffmann M, Herrmann M. Aggregated neutrophil extracellular traps limit inflammation by degrading cytokines and chemokines. Nat Med. 2014; 20(5): 511-517.
4. Muñoz LE, Bilyy R, Biermann MH, Kienhöfer D, Maueröder C, Hahn J, Brauner JM, Weidner D, Chen J, Scharin-Mehlmann M, Janko C, Friedrich RP, Mielenz D, Dumych T, Lootsik MD, Schauer C, Schett G, Hoffmann M, Zhao Y, Herrmann M. Nanoparticles sizedependently initiate self-limiting NETosisdriven inflammation. Proc Natl Acad Sci USA. 2016; 113(40): E5856-E5865.

5. Brinkmann V, Reichard U, Goosmann C, Fauler B, Uhlemann Y, Weiss DS, Weinrauch Y, Zychlinsky A. Neutrophil extracellular traps kill bacteria. Science. 2004 Mar 5;303(5663):1532-5.

6. Kirchner T, Möller S, Klinger M, Solbach W, Laskay T, Behnen $\mathrm{M}$. The impact of various reactive oxygen species on the formation of neutrophil extracellular traps. Mediators Inflamm. 2012; 2012: 849136.

7. Bilyy R, Fedorov V, Vovk V, Leppkes M, Dumych T, Chopyak V, Schett G, Herrmann M. Neutrophil Extracellular Traps Form a Barrier between Necrotic and Viable Areas in Acute Abdominal Inflammation. Front Immunol. 2016; 7: 424.

8. Podolska MJ, Mahajan A, Knopf J, Hahn J, Boeltz S, Munoz L, Bilyy R, Herrmann M. Autoimmune, rheumatic, chronic inflammatory diseases: Neutrophil extracellular traps on parade. Autoimmunity. 2018; 51(6): 281-287.

9. Sin YM, Sedgwick AD, CheaEP, Willoughby DA. Mast cells in newly formed lining tissue during acute inflammation: a six day air pouch model in the mouse. Ann Rheum Dis. 1986; 45(10): 873877.

10. Chorna I, Bilyy R, Datsyuk L, Stoika R. Comparative study of human breast carcinoma MCF-7 cells differing in their resistance to doxorubicin: effect of ionizing radiation on apoptosis and TGF-beta production. Exp Oncol. 2004; 26(2): 111-117.

11. Ngan J, Kind LS. Suppressor T cells for IgE and IgG in Peyer's patches of mice made tolerant by the oral administration of ovalbumin. J Immunol. 1978; 120(3): 861-865.

12. O'Hagan DT, Jeffery H, Davis SS. Longterm antibody responses in mice following subcutaneous immunization with ovalbumin entrapped in biodegradable microparticles. Vaccine. 1993; 11(9): 965-999.

13. Mota I, Wong D. Homologous and heterologous passive cutaneous anaphylactic activity of mouse 
antisera during the course of immunization. Life Sci. 1969; 8(16): 813-820.

14. Allen IC. Delayed-type hypersensitivity models in mice. Methods Mol Biol. 2013; 1031: 101-107.

15. Bilyy R, Paryzhak S, Turcheniuk K, Dumych T, Barras A, Boukherroub R, et al. Aluminum oxide nanowires as safe and effective adjuvants for next-generation vaccines. Mater Today. 2019; 22: 58-66.

16. Stephen J, Scales HE, Benson RA, Erben D, Garside P, Brewer JM. Neutrophil swarming and extracellular trap formation play a significant role in Alum adjuvant activity. NPJ Vaccines. 2017; 2(1): 1.

17. Biermann MH, Podolska MJ, Knopf J, Reinwald C, Weidner D, Maueröder C, Hahn J, Kienhöfer D, Barras A, Boukherroub R, Szunerits S, Bilyy R, Hoffmann M, Zhao Y, Schett G, Herrmann M, Munoz LE. Oxidative Burst-Dependent NETosis Is Implicated in the Resolution of Necrosis-Associated Sterile Inflammation. Front Immunol. 2016; 7: 557.

18. Bianco A. Graphene: safe or toxic? The two faces of the medal. Angew Chem Int Ed Engl. 2013; 52(19): 4986-4997.

19. Li C, Ye R, Bouckaert J, Zurutuza A, Drider D, Dumych T, Paryzhak S, Vovk V, Bilyy RO,
Melinte S, Li M, Boukherroub R, Szunerits S. Flexible Nanoholey Patches for Antibiotic-Free Treatments of Skin Infections. ACS Appl Mater Interfaces. 2017; 9(42): 36665-36674.

20. Prylutska S, Bilyy R, Schkandina T, Bychko A, Cherepanov V, Andreichenko K, Stoika R, Rybalchenko V, Prylutskyy Y, Scharff P, Ritter U. Effect of iron-doped multi-walled carbon nanotubes on lipid model and cellular plasma membranes. Mater Sci Eng C Mater Biol Appl. 2012; 32(6): 1486-1489.

21. Lategan K, Fowler J, Bayati M, Fidalgo de Cortalezzi M, Pool E. The Effects of Carbon Dots on Immune System Biomarkers, Using the Murine Macrophage Cell Line RAW 264.7 and Human Whole Blood Cell Cultures. Nanomaterials (Basel). 2018; 8(6). pii: E388.

22. Chen BX, Wilson SR, Das M, Coughlin DJ, Erlanger BF. Antigenicity of fullerenes: antibodies specific for fullerenes and their characteristics. Proc Natl Acad Sci USA. 1998; 95(18): 10809-10813.

23. Andreev SM, Babakhin AA, Petrukhina AO, Romanova VS, Parnes ZN, Petrov RV. Immunogenic and allergenic properties of fulleren conjugates with aminoacids and proteins. Dokl Biochem. 2000; 370(1-6): 4-7. 